\title{
Foamability of Cellulose Palmitate Using Various Physical Blowing Agents in the Extrusion Process
}

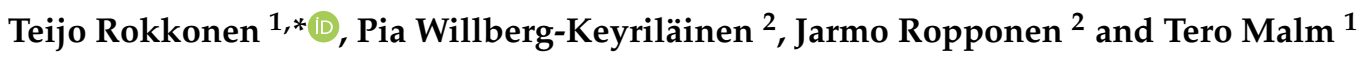 \\ 1 VTT Technical Research Centre of Finland Ltd., Visiokatu 4, P.O. Box 1300, FI-33101 Tampere, Finland; \\ tero.malm@vtt.fi \\ 2 VTT Technical Research Centre of Finland Ltd., Tietotie 4E, P.O Box 1000, FI-02044 Espoo, Finland; \\ pia.willberg-keyrilainen@vtt.fi (P.W.-K.); jarmo.ropponen@vtt.fi (J.R.) \\ * Correspondence: teijo.rokkonen@vtt.fi
}

Citation: Rokkonen, T;;

Willberg-Keyriläinen, P.; Ropponen, J.; Malm, T. Foamability of Cellulose

Palmitate Using Various Physical

Blowing Agents in the Extrusion

Process. Polymers 2021, 13, 2416.

https: / / doi.org/10.3390/

polym13152416

Academic Editor: Judith

Martín-de León

Received: 5 July 2021

Accepted: 21 July 2021

Published: 23 July 2021

Publisher's Note: MDPI stays neutral with regard to jurisdictional claims in published maps and institutional affiliations.

Copyright: (c) 2021 by the authors. Licensee MDPI, Basel, Switzerland. This article is an open access article distributed under the terms and conditions of the Creative Commons Attribution (CC BY) license (https:// creativecommons.org/licenses/by/ $4.0 /)$.

\begin{abstract}
Polymer foams are widely used in several fields such as thermal insulation, acoustics, automotive, and packaging. The most widely used polymer foams are made of polyurethane, polystyrene, and polyethylene but environmental awareness is boosting interest towards alternative bio-based materials. In this study, the suitability of bio-based thermoplastic cellulose palmitate for extrusion foaming was studied. Isobutane, carbon dioxide $\left(\mathrm{CO}_{2}\right)$, and nitrogen $\left(\mathrm{N}_{2}\right)$ were tested as blowing agents in different concentrations. Each of them enabled cellulose palmitate foam formation. Isobutane foams exhibited the lowest density with the largest average cell size and nitrogen foams indicated most uniform cell morphology. The effect of die temperature on foamability was further studied with isobutane ( $3 \mathrm{wt} \%$ ) as a blowing agent. Die temperature had a relatively low impact on foam density and the differences were mainly encountered with regard to surface quality and cell size distribution. This study demonstrates that cellulose palmitate can be foamed but to produce foams with greater quality, the material homogeneity needs to be improved and researched further.
\end{abstract}

Keywords: cellulose; cellulose ester; foaming; foam extrusion

\section{Introduction}

Polymer foams, also known as cellular plastics, are an important polymeric material. Cellular structure is formed from a combination of gaseous and solid phases. Foams can be closed-cell or open-cell in structure. In general, closed-cell foams are more rigid, whereas open-cell foams are usually flexible. Depending on the structure and material, polymer foams can have a low density, good thermal and sound insulation properties, and high specific strength. Therefore, these foam materials have been widely used in the fields of thermal insulation, acoustics, automotive, packaging, sports equipment, and construction [1-4]. Additionally, foaming is an efficient way to reduce the required amount of material and therefore cost [5].

Extrusion foaming is one of the primary foaming processes due to its continuous nature especially for polyolefins, polystyrene, and vinyl plastics [3]. In extrusion foaming, porous structures are achieved by incorporating a blowing agent into the polymer melt. Blowing agents can be divided into physical and chemical blowing agents depending on the gas production method. Physical blowing agents are, for example, low boiling point organic hydrocarbons (e.g., isobutane and pentane) [6-8] or inorganic materials (e.g., nitrogen, carbon dioxide, water, and argon) [7-13] that are added to the polymer matrix as liquid or gas and usually go through a phase change during foaming. Chemical blowing agents (e.g., sodium bicarbonate, citric acid, and azodicarbonamide) [14-16] produce gaseous products through chemical reactions, usually decomposition upon heating. Nucleating agents (e.g., talc and calcium carbonate) are used for controlling the cellular structure of foams (e.g., distribution, number, and size of cells). Without a nucleating agent, the number 
of cells might be low and the average cell size may be large, causing difficulty to produce low-density foams with uniform cell morphology $[17,18]$.

The most widely used polymer foams are made of polyurethane (PU), polystyrene (PS), polyethylene (PE), or poly(vinyl chloride) (PVC). These conventional polymers are petrochemical derivatives and are not bio-based. However, environmental awareness, new legislative initiatives, and depletion of non-renewable resources have been boosting interest towards more sustainable bio-based materials. Considerable efforts are therefore being made to replace petrochemical-based polymeric foams with foams based on renewable resources such as starch [19-23] or poly(lactic acid) (PLA) [7,24-27].

Cellulose-based thermoplastics are also a promising biopolymer group for replacing synthetic foams in certain foam applications. However, only some results of cellulosebased extrusion foams have been reported [28-34]. Cellulose acetate (CA) is one of the cellulose derivatives that have been recognized as suitable for foam extrusion $[28,30,32]$. Pure cellulose acetate is thermoplastic material with a glass transition close to its thermal decomposition temperature that narrows its processing temperature area. Therefore, pure CA cannot be processed using extrusion foaming without external plasticizers [28,35]. In our previous studies, we have developed thermoplastic long-chain cellulose esters that can be processed without the addition of plasticizers. These long-chain cellulose esters are $100 \%$ bio-based material and processable at low temperatures $\left(\sim 130^{\circ} \mathrm{C}\right)[36-38]$.

In this study, the suitability of cellulose palmitate ester for extrusion foaming was examined. The cellulose palmitate was prepared according to our earlier study. It has also been reported that the cellulose palmitate can be used to compensate for the use of fossilbased injection molding plastics and melt-spun fibers; thus, it was assumed that cellulose palmitate would also work well in the extrusion foaming process [39,40]. Foamability of cellulose palmitate was studied using three physical blowing agents. Additionally, the effect of foaming temperature on foamability was studied.

\section{Materials and Methods}

\subsection{Materials}

Commercial softwood dissolving-grade pulp purchased from Domsjö Fabriker AB (Örnsköldsvik, Sweden) was used as a starting material and the pulp was pre-treated with ozone according to the method described by Willberg-Keyriläinen et al. [36]. Lithium chloride ( $\mathrm{LiCl}$ ), N,N-Dimethylacetamide (DMAc), palmitoyl chloride, pyridine, and acetone were analytical grade and purchased from Sigma-Aldrich (Espoo, Finland). Technical ethanol was purchased from Altia Oyj (Helsinki, Finland).

Three different physical blowing agents were used to prepare the cellulose palmitate foams. Carbon dioxide, nitrogen, and isobutane R600a (IB) were purchased from Linde Group (Espoo, Finland). The blowing agent content was varied during foaming to find the optimal dosing. Finntalc M05SL (median particle size $2.2 \mu \mathrm{m}$, Mondo Minerals Oy, Outokumpu, Finland) was used as a nucleating agent.

\subsection{Preparation of Cellulose Palmitate}

The cellulose palmitate was prepared using the homogeneous method presented by Willberg-Keyriläinen et al. [36,37]. In this method, dry cellulose was first dissolved in a 5\% $\mathrm{LiCl} / \mathrm{DMAc}$ solution. Then, palmitoyl chloride 3 equivalents to the cellulose anhydroglucose unit (AGU) was added to the cellulose mixture using pyridine (3.6 equivalents/AGU) as a catalyst. The reaction temperature was $80^{\circ} \mathrm{C}$ and the reaction time was $16 \mathrm{~h}$. The product was precipitated with ethanol and washed first with ethanol and then acetone. The degree of substitution (DS) of the prepared cellulose palmitate was 1.0 (according to the solid-state NMR).

\subsection{Extrusion Foaming}

Foams were prepared with the Brabender Plastograph EC plus $19 \mathrm{~mm}$ singe screw extruder (Brabender GmbH \& Co KG, Duisburg, Germany). The extruder was also equipped 
with a $0.66 \mathrm{~cm}^{3} / \mathrm{rev}$ melt pump and static mixer-type melt cooler with oil tempering. The extruder screw geometry appropriate for foaming was used that has a three-phase compression process and an increase in inner diameter at the blowing agent injection point. The extruder barrel was heated with 3 heating bands (zones) and the blowing agent was injected between zones 2 and 3 . The extruder was also equipped with a round capillary die. The die geometry was $2 / 20$ (diameter/length in $\mathrm{mm}$ ).

Blowing agents were injected and pressurized with the Teledyne ISCO dual-syringe pump system (Teledyne ISCO Inc., Lincoln, NE, USA). As carbon dioxide and isobutane can be liquefied, they were also dosed with the Teledyne pump. The injection pressure for carbon dioxide and isobutane was 120 bar and 85 bar, respectively. In order to aid liquefaction, the pump was cooled to $2{ }^{\circ} \mathrm{C}$. As nitrogen cannot be liquefied easily, it was injected as gas. Nitrogen dosing was conducted using the Bronkhorst EL-FLOW mass flow controller (Bronkhorst High-Tech B.V., Ruurlo, The Netherlands). Still, the Teledyne pump was used to pressurize the nitrogen gas to 200 bar. The blowing agent dosage was calculated as a mass percentage based on the material throughput determined by measuring a 1 min sample by hand.

During the foam processing, the extruder barrel temperatures and melt pump temperatures were kept constant. The temperature profile was $130^{\circ} \mathrm{C}, 135^{\circ} \mathrm{C}, 135^{\circ} \mathrm{C}, 135^{\circ} \mathrm{C}$. Therefore, to prepare the sample, only the melt cooler and die temperatures were changed. Other processing-related variables included the blowing agent concentration, melt pump RPM (material throughput), and die geometry. When a foam sample was taken, the die pressure was recorded with Brabender WinEXT software (Version 4.9.0, Brabender GmbH \& Co KG, Duisburg, Germany). The extrusion foaming setup is presented in Figure 1.

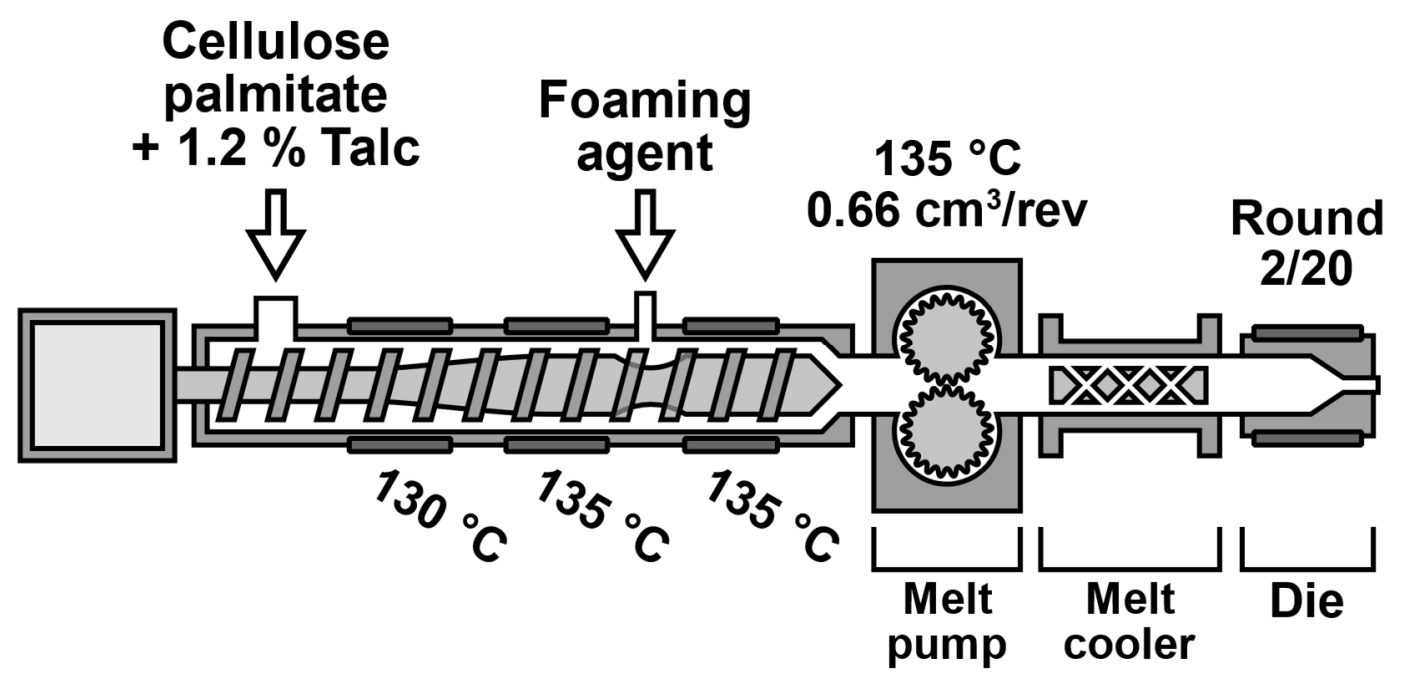

Figure 1. Extrusion foaming setup.

Cellulose palmitate material was dried under vacuum at $30{ }^{\circ} \mathrm{C}$ overnight. Additionally, the extruder hopper was shielded with nitrogen gas flow $(\sim 5 \mathrm{~L} / \mathrm{min})$ to prevent the material from absorbing moisture. The nucleating agent was dry-blended by hand in a bag with the cellulose palmitate before processing. The amount of nucleating agent was kept constant at $1.2 \mathrm{wt} \%$.

\subsection{Density Measurement}

Due to the irregular shapes of the prepared foams, the densities were determined with a liquid submersion technique. Water purified with reverse osmosis was used as the liquid media. Surfactant was used to reduce the surface tension of the water to prevent microbubbles from forming on the foam surfaces during submersion. Additionally, as the sample foams are closed cell and the material is impermeable to water, ingress of water into the foam cells is not expected. Four parallel measurements were made from each foam 
sample. The foams were weighed with the Mettler Toledo XS205 DualRange scale (Mettler Toledo, Columbus, OH, USA).

\subsection{Scanning Electron Microscopy}

Scanning electron microscope (SEM) images were taken in order to determine the cell size, wall thickness, and general cell structure. Images were captured with JEOL JSM-6360LV (JEOL Ltd., Tokyo, Japan). A small section of the foam extrudate was frozen in liquid nitrogen and fractured. The fractured surfaces were then gold-coated with the Bal-Tec SCD050 (BalTec, Balzers, Liechtenstein) sputter coater. An acceleration voltage of $7 \mathrm{kV}$ was used and the images were constructed from secondary electrons.

\subsection{Tomography}

Cell size distribution was analyzed using $\mathrm{X}$-ray micro-computed tomography $(\mathrm{X} \mu \mathrm{CT})$. Samples were imaged using the Rx Solutions desktom 130 scanner ( $R X$ solutions, Chavanod, France). An acceleration voltage of $40 \mathrm{kV}$ and a voxel size of $3.7 \mu \mathrm{m}$ were used. Scanning time was around $60 \mathrm{~min}$ per sample. To measure pore sizes, local thickness transform was used [41]. The local thickness transform fits spheres into the structure such that the spheres fill the void space optimally. The method defines for each voxel the maximal sphere it belongs to. This allows for the calculation of the volume-normalized probability distribution for the pore sizes.

\section{Results and Discussion}

\subsection{Effect of Blowing Agents}

The foaming parameters used in the preparation of cellulose palmitate foam samples with isobutane, carbon dioxide, and nitrogen are presented in Table 1. Samples were prepared with a melt cooler at a lower temperature than the die. The goal was to reduce the material temperature significantly while heating only the surface of the material at the die to prevent the die from clogging. The aim was also to maintain the same temperatures with varying blowing agent concentration. The sample $\mathrm{CO}_{2}-0.5$ was produced at a higher die temperature $\left(120^{\circ} \mathrm{C}\right)$ than the other $\mathrm{CO}_{2}$ samples $\left(115^{\circ} \mathrm{C}\right)$ as temperatures below $120^{\circ} \mathrm{C}$ caused the material to freeze at the die. Carbon dioxide at $0.5 \%$ did not provide enough plasticization to the material in order to reach the lower processing temperature. Maximum blowing agent concentrations for isobutane, carbon dioxide, and nitrogen were $5 \%, 3 \%$, and $1 \%$, respectively. The maximum blowing agent amount was determined in-situ by evaluating the foaming behavior of the extruded material. With an excessively high amount of blowing agent, the foam would rupture prematurely, producing a slight popping sound, and collapse. The amount of maximum blowing agent is related to the blowing agent solubility to the cellulose palmitate as well as to the relationship between the material melt strength and specific volume of the blowing agent [42].

Table 1. Foaming parameters of prepared cellulose palmitate foam samples.

\begin{tabular}{|c|c|c|c|c|c|c|c|}
\hline \multirow{2}{*}{ Sample ID } & \multicolumn{2}{|c|}{ Blowing Agent } & \multicolumn{2}{|c|}{ Temperature $\left[{ }^{\circ} \mathrm{C}\right]$} & \multirow{2}{*}{$\begin{array}{l}\text { Die } \\
\text { Geom. }\end{array}$} & \multirow{2}{*}{$\begin{array}{c}\text { Die Pressure } \\
\text { [bar] }\end{array}$} & \multirow{2}{*}{$\begin{array}{c}\text { Throughput } \\
\text { [g/min] }\end{array}$} \\
\hline & Type & wt $\%$ & Melt Cooler & Die & & & \\
\hline IB-1 & Isobutane & 1 & 120 & 125 & $2 / 20$ & 125 & 14 \\
\hline IB-3 & Isobutane & 3 & 120 & 125 & $2 / 20$ & 101 & 14 \\
\hline IB-5 & Isobutane & 5 & 120 & 125 & $2 / 20$ & 67 & 14 \\
\hline $\mathrm{CO}_{2}-0.5$ & Carbon dioxide & 0.5 & 110 & 120 & $2 / 20$ & 150 & 14 \\
\hline $\mathrm{CO}_{2}-1$ & Carbon dioxide & 1 & 110 & 115 & $2 / 20$ & 163 & 14 \\
\hline $\mathrm{CO}_{2}-3$ & Carbon dioxide & 3 & 110 & 115 & $2 / 20$ & 101 & 14 \\
\hline $\mathrm{N}_{2}-0.5$ & Nitrogen & 0.5 & 110 & 120 & $2 / 20$ & 151 & 28 \\
\hline $\mathrm{N}_{2}-1$ & Nitrogen & 1 & 110 & 120 & $2 / 20$ & 145 & 28 \\
\hline
\end{tabular}

A blowing agent is known to reduce the polymer material viscosity. During the foaming process, blowing agents act as a plasticizer and increase the free volume $[43,44]$. To 
completely dissolve the blowing agent, adequate pressure is needed. To achieve adequate pressure, a certain viscosity of the polymer melt is required. This is usually achieved by reducing the processing temperature to compensate for the viscosity reduction caused by a blowing agent $[28,44]$. The effect can also be observed in our experiments as a reduction in die pressure when the amount of blowing agent was increased. While it is challenging to evaluate the plasticization effect of blowing agents on a material without proper measurement, die pressure can be used to determine an estimate on the matter, especially considering throughput and die geometry were kept constant. If we compare samples IB-3 and $\mathrm{CO}_{2}-3$ that were made with the same amount of blowing agent, they both produced a die pressure of 101 bar. However, $\mathrm{CO}_{2}-3$ did so with $10^{\circ} \mathrm{C}$ lower melt cooler and die temperatures, indicating that the plasticization effect of carbon dioxide is higher than that of isobutane. The effect of nitrogen is more difficult to evaluate and compare due to the increased throughput. Nitrogen was used at a higher material throughput in order to increase nitrogen feeding accuracy with the utilized mass flow controller. However, generally nitrogen is far less soluble and therefore has less plasticization capability than carbon dioxide $[45,46]$.

All three physical blowing agents were able to foam the cellulose palmitate material successfully. The visual appearance of the produced foam strands is presented in Figure 2. While foams produced with low blowing agent concentrations share some visual characteristics, foams produced with a higher concentration exhibit differences between blowing agents more effectively. Foams produced with isobutane have a higher expansion than nitrogen and carbon dioxide which are closer to each other. Surface quality or foam uniformity was not particularly good with any of the foamed samples which is probably related to the material properties themselves rather than strictly the blowing agent. However, differences in the surface quality between blowing agents can be detected. Arguably, carbon dioxide produced the most non-uniform surface for the foams at the $3 \%$ dosage. While isobutane also produced a foam with relatively rough surface quality, the surface texture was more consistent than the carbon dioxide foam. Additionally, a sample foamed with 3\% isobutane had a smoother surface than the 5\% isobutane sample that had clearly shrunk. Foams produced with nitrogen had the smoothest surface (looking past material irregularities) and the highest shine.

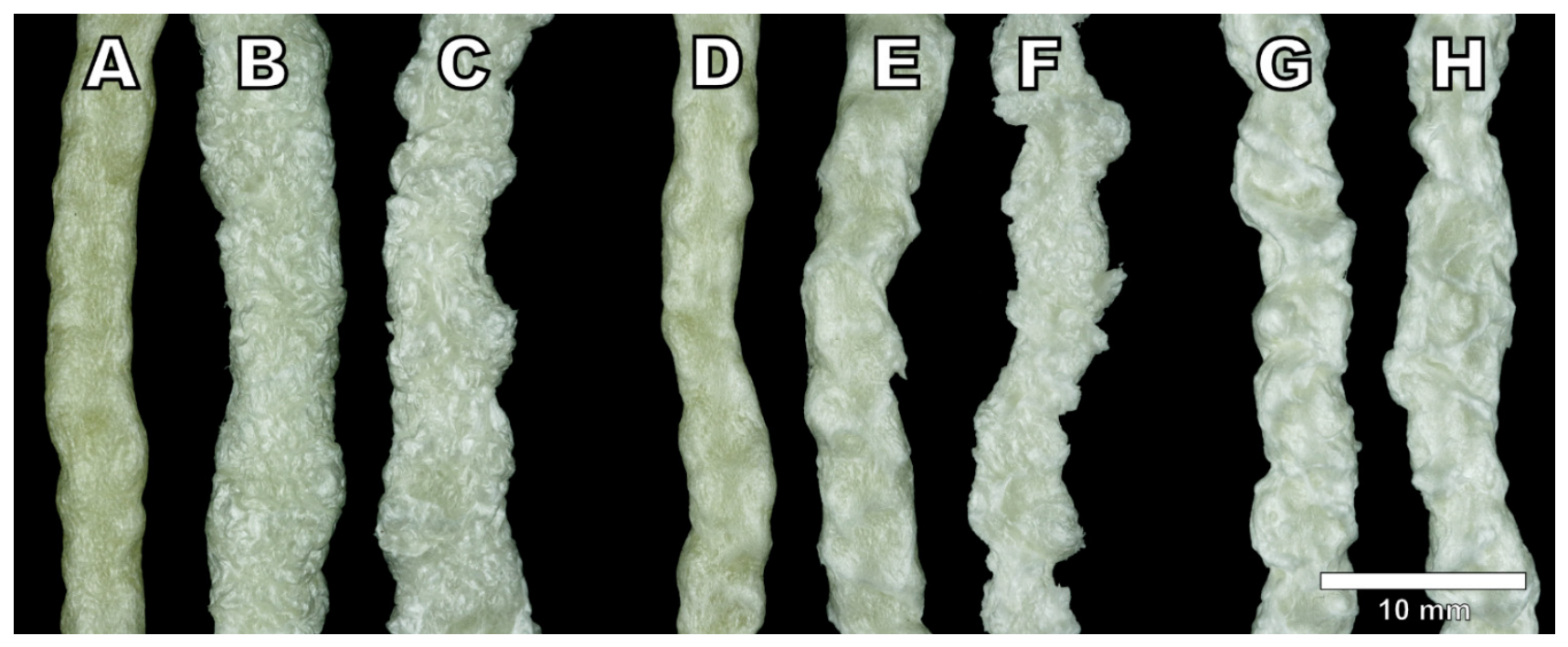

Figure 2. Side profiles of produced cellulose palmitate foams: (A) IB-1, (B) IB-3, (C) IB-5, (D) $\mathrm{CO}_{2}-0.5,(\mathbf{E}) \mathrm{CO}_{2}-1,(\mathbf{F}) \mathrm{CO}_{2}-3$, (G) $\mathrm{N}_{2}-0,5$, and $(\mathbf{H}) \mathrm{N}_{2}-1$. The scale is approximate.

Foam morphologies determined with SEM imaging are presented in Figures 3-5. As observed by the visual appearance, the lowest amounts of isobutane (1\%, Figure $3 \mathrm{~A})$ and carbon dioxide $(0.5 \%$, Figure $4 \mathrm{~A})$ produced very similar foam morphologies. The amount 
of blowing agent in these samples has not been high enough to fully foam the material. The formed cells are scattered around the material without neighboring cells sharing a cell wall producing a very low foaming degree. The foam densities presented in Table 2 display that the samples IB- 1 and $\mathrm{CO}_{2}-0.5$ also have very similar densities of $0.47 \mathrm{~g} \mathrm{~cm}^{-3}$ and $0.45 \mathrm{~g} \mathrm{~cm}^{-3}$, respectively.
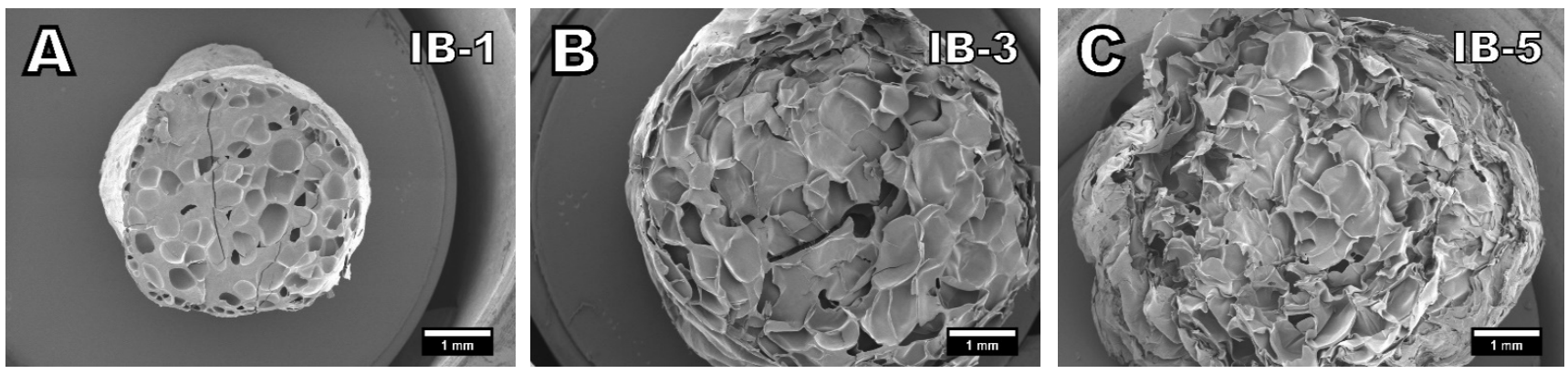

Figure 3. SEM images of samples foamed with isobutane in amounts of (A) $1 \%$, (B) $3 \%$, and (C) $5 \%$. (15× magnification).
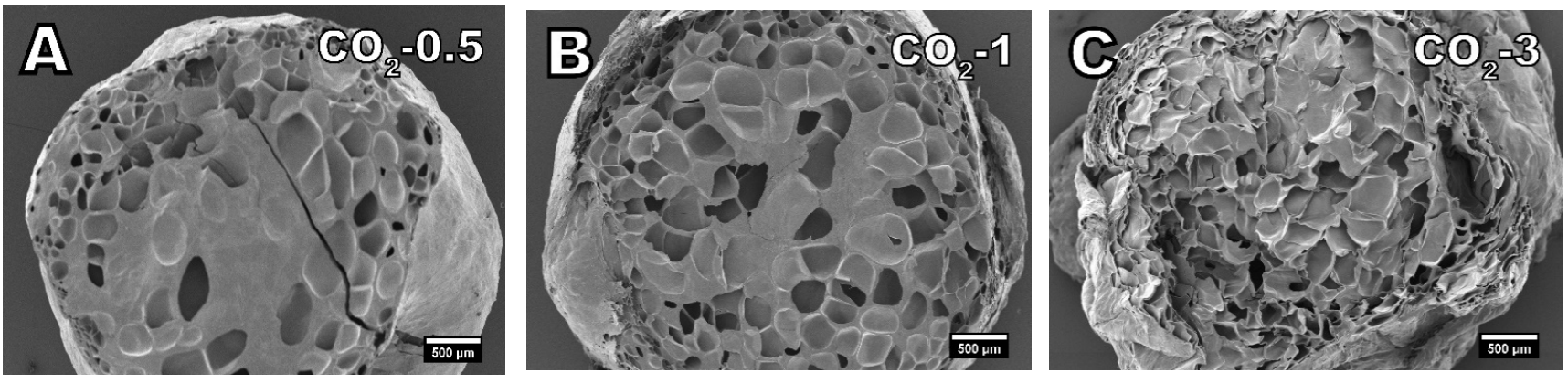

Figure 4. SEM images of samples foamed with carbon dioxide in amounts of (A) $0.5 \%$, (B) $1 \%$, and (C) $3 \%$. (25× magnification).
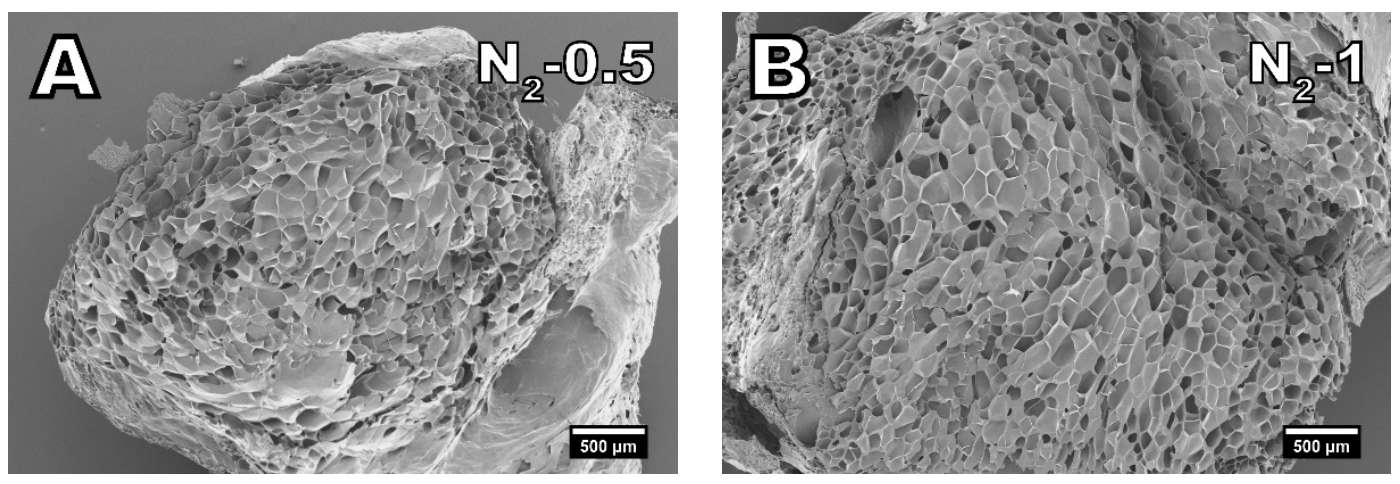

Figure 5. SEM images of samples foamed with nitrogen in amounts of (A) $0.5 \%$ and (B) $1 \%$. (25× magnification).

Samples with 3\% isobutane (Figure 3B) and 1\% carbon dioxide are relatively comparable in terms of densities as well. IB-3 had a density of $0.20 \mathrm{~g} \mathrm{~cm}^{-3}$ and $\mathrm{CO}_{2}-1$ had a density of $0.24 \mathrm{~g} \mathrm{~cm}^{-3}$. Figure $4 \mathrm{~B}$ shows that $1 \%$ of carbon dioxide has not fully foamed the material as there are areas with no cells present, resulting in the slightly higher density. However, the cells that have formed are relatively spherical in shape and the cell structure shows no signs of collapse. The same cannot be said about the sample of IB-3 foamed with $3 \%$ isobutane. Figure 3B shows that while the material has been fully foamed, the cell structure had collapsed and the cells lost their spherical form. The cell collapse is also the reason for the rough surface quality of the IB-3 sample. 
Table 2. Densities of prepared cellulose palmitate foams.

\begin{tabular}{cc}
\hline Sample ID & Density $\left[\mathrm{g} \mathrm{cm}^{-3}\right]$ \\
\hline IB-1 & $0.47 \pm 0.07$ \\
IB-3 & $0.20 \pm 0.02$ \\
IB-5 & $0.17 \pm 0.01$ \\
$\mathrm{CO}_{2}-0.5$ & $0.45 \pm 0.02$ \\
$\mathrm{CO}_{2}-1$ & $0.24 \pm 0.01$ \\
$\mathrm{CO}_{2}-3$ & $0.19 \pm 0.01$ \\
$\mathrm{~N}_{2}-0.5$ & $0.18 \pm 0.00$ \\
$\mathrm{~N}_{2}-1$ & $0.19 \pm 0.00$ \\
\hline
\end{tabular}

Cell collapse is more pronounced on the samples IB- 5 and $\mathrm{CO}_{2}-3$. In particular, the sample foamed with 5\% isobutane (Figure 3C) had severely collapsed cell structure to the point where it is difficult to distinguish between individual cells. This is also clearly visible based on the visual appearance of the foams (Figure 2) as IB-5 had shrunk much more than IB-3 and had a worse surface quality. Die pressure on the sample IB- 5 was only $67 \mathrm{bar}$, indicating that there is still more headroom in the die pressure and the viscosity has been relatively low. Therefore, it is possible that more stable foam with less cell collapse could have been achieved with a lower foaming temperature and increased viscosity. Nevertheless, the highest expansion ratio and the lowest density was achieved with $5 \%$ isobutane. A similar trend can be seen with a sample of $\mathrm{CO}_{2}-3$ that had the highest amount of carbon dioxide. The cells have lost their spherical shape and the cells walls are wrinkled. This also results in rough surface quality. While carbon dioxide could benefit from reduced foaming temperature to achieve cells with better form, the effect might be more limited with carbon dioxide than isobutane due to blowing agent diffusion during aging.

When a foam structure is closed cell as these samples are, the blowing agent has to permeate through the cell walls. Simultaneously, air (mostly nitrogen) permeates into the cells, replacing the blowing agent until equilibrium is reached. Isobutane and carbon dioxide are eventually replaced by air. If the blowing agent diffusion rate is faster than that of air, the cells have a small vacuum that can cause the cells to shrink or collapse due to poor cell wall stiffness [47]; this is especially the case with carbon dioxide. Carbon dioxide is a much smaller molecule than, for example, isobutane and it tends to permeate the cells faster. This effect has been encountered with PLA foams [7]. While gas permeation values of cellulose palmitate are not known, in some cellulose based thermoplastics, permeation of carbon dioxide is higher than that of nitrogen [48].

When nitrogen is used as a blowing agent, the diffusion of nitrogen out of the cells can be considered to be in equilibrium with air diffusing into the cells. Therefore, shrinkage with nitrogen is negligible. Figure 5 displays the cell morphology of samples foamed with nitrogen. The cells in the samples $\mathrm{N}_{2}-0.5$ and $\mathrm{N}_{2}-1$ show no signs of shrinking or collapse as the cell walls are not creased. Furthermore, compared to isobutane and carbon dioxide, the material is fully foamed even at a low nitrogen dosage of $0.5 \%$. Despite the comparatively low dosage of nitrogen, samples $\mathrm{N}_{2}-0.5$ and $\mathrm{N}_{2}-1$ have a similarly low density of around $0.19 \mathrm{~g} \mathrm{~cm}^{-3}$ as IB-5 and $\mathrm{CO}_{2}-3$. Nitrogen has the highest specific volume followed by carbon dioxide and isobutane [49]. Therefore, less nitrogen is necessary to achieve the same expansion than for carbon dioxide or isobutane.

The average cell size and cell density are a combination of several foaming parameters such as pressure drop rate, level of supersaturation, use of nucleating agents, temperature, and blowing agent [50,51]. The average cell size and cell density of the cellulose palmitate foams is different with all three blowing agents. While it is difficult to quantitatively measure the average cell size due to collapsed cell structures of carbon dioxide and isobutane foams, some visual estimations can be made. By far the smallest and most uniform cell size with the highest cell density was achieved with nitrogen. Nitrogen also produced the thinnest cell walls. Isobutane produced the largest cell size, whereas carbon dioxide produced cells between isobutane and carbon dioxide. However, considering that the pressure 
drop rate has a significant effect on cell density and the samples were not produced with equal pressure drop rates, the evaluation of the blowing agent effect on cell density and average cell size is slightly limited [52,53]. Nevertheless, nitrogen is known to have a better nucleation capability and to produce higher cell density than carbon dioxide $[45,54]$. Cell density was also increased when the blowing agent content was increased. This is expected due to the higher level of supersaturation increasing the driving force of nucleation. Similar results as discussed here were reported by Kim et al. [8] with nitrogen, carbon dioxide, and n-butane.

The density results in Table 2 indicate that the density of the cellulose palmitate foams decreased significantly as the blowing agent content increased except for samples in which nitrogen was used. In these foams, the density remained the same even though the amount of blowing agent doubled. While the solubility of nitrogen to cellulose palmitate is not known, it is possible that the additional amount of nitrogen after $0.5 \%$ has not completely dissolved in the melt. It has been reported that increasing nitrogen can have diminishing returns on void fraction and cell density in high-density foams $[5,9,55]$.

\subsection{Effect of Foaming Temperature}

Based on the results of the blowing agent survey, one blowing agent was selected for further foaming temperature studies with cellulose palmitate. Based on cell morphology and density measurements, nitrogen would seem like the logical choice considering it produced foams with the most uniform cell structure and low density. However, while proper mechanical tests were not conducted, the strength of each foam was estimated by hand. The foams prepared with nitrogen had virtually no strength and were quite brittle in nature. Therefore, the selection of the blowing agent was narrowed down to carbon dioxide and isobutane. From these two very similarly behaving blowing agents, better surface quality and visual uniformity was achieved with isobutane. Isobutane foams exhibited significant cell collapse but based on the blowing agent diffusion rates, isobutane could benefit more from temperature adjustment or at least the effect of foaming temperature may be clearer. Therefore, isobutane was selected.

Foaming parameters used in the isobutane temperature survey are presented in Table 3. The amount of isobutane was fixed to 3\%. Considering the foam prepared with isobutane had the largest average cell size, the throughput was also doubled in hopes of faster pressure drop rate, increased nucleation, and smaller average cell size. For simplicity, melt cooler and die temperature were always set to the same temperature. The foaming temperature was between $105{ }^{\circ} \mathrm{C}$ and $130{ }^{\circ} \mathrm{C}$ with $5{ }^{\circ} \mathrm{C}$ increments. The lower limit for foaming temperature was determined to be when die pressure reached 200 bar.

Table 3. Processing parameters used during production of temperature survey samples.

\begin{tabular}{|c|c|c|c|c|c|c|c|}
\hline \multirow{2}{*}{ Sample ID } & \multicolumn{2}{|c|}{ Blowing Agent } & \multicolumn{2}{|c|}{ Temperature $\left[{ }^{\circ} \mathrm{C}\right]$} & \multirow{2}{*}{$\begin{array}{c}\text { Die } \\
\text { geom. }\end{array}$} & \multirow{2}{*}{$\begin{array}{c}\text { Die Pressure } \\
\text { [bar] }\end{array}$} & \multirow{2}{*}{$\begin{array}{l}\text { Throughput } \\
{\left[\mathrm{g} \mathrm{min}^{-1}\right]}\end{array}$} \\
\hline & Type & $\mathbf{w t} \%$ & Melt Cooler & Die & & & \\
\hline IB-3_130 ${ }^{\circ} \mathrm{C}$ & Isobutane & 3 & 130 & 130 & $2 / 20$ & 81 & 28 \\
\hline IB-3_125 $12{ }^{\circ} \mathrm{C}$ & Isobutane & 3 & 125 & 125 & $2 / 20$ & 102 & 28 \\
\hline IB-3_120 $120^{\circ} \mathrm{C}$ & Isobutane & 3 & 120 & 120 & $2 / 20$ & 130 & 28 \\
\hline IB-3_ $115^{\circ} \mathrm{C}$ & Isobutane & 3 & 115 & 115 & $2 / 20$ & 143 & 28 \\
\hline IB-3_ $110^{\circ} \mathrm{C}$ & Isobutane & 3 & 110 & 110 & $2 / 20$ & 165 & 28 \\
\hline IB-3_ $105^{\circ} \mathrm{C}$ & Isobutane & 3 & 105 & 105 & $2 / 20$ & 200 & 28 \\
\hline
\end{tabular}

Foam side profiles presented in Figure 6 show that the surface is coarse at temperatures of $130^{\circ} \mathrm{C}$ and $125^{\circ} \mathrm{C}$. When temperature is decreased, the foam surface becomes smoother. Reduction in foaming temperature also reduces the strand diameter. However, this is difficult to estimate due to the irregular surfaces. This is expected considering at a high temperature, foam expansion is governed by gas loss, and at a lower temperature foam expansion can be reduced due to an increase in viscosity and material solidification [56]. At a high temperature, the diffusion of isobutane is fast and the stiffness of the material is too 
low to accommodate the loss of gas. This results in high expansion but also a high amount of shrinking. At a low temperature, the blowing agent does not have enough expansion power to fully foam the material. Some melt fracture is also present at $105^{\circ} \mathrm{C}$, indicating that the lower processing temperature had been reached.

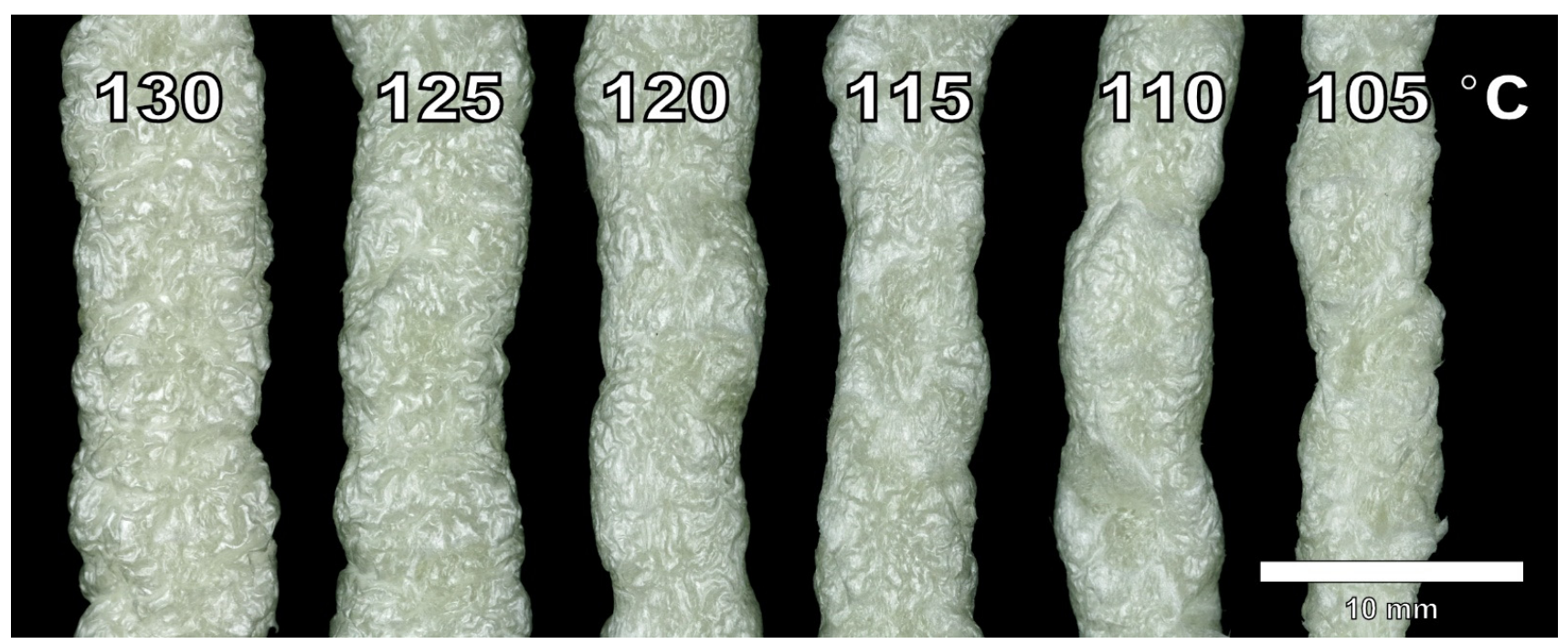

Figure 6. Side profiles from the produced cellulose palmitate foams using different foaming temperatures and $3 \%$ IB as a blowing agent. Refer to Table 3. The scale is approximate.

The cause for the shrunken surface of samples foamed at $130{ }^{\circ} \mathrm{C}$ and $125^{\circ} \mathrm{C}$ is visible on the SEM images presented in Figure 7. The cells of these two samples have lost their spherical shape and the cell walls are slightly bent. Under $120{ }^{\circ} \mathrm{C}$, the foam morphology starts to become more uniform. Based on the SEM analysis, the most uniform cell structure was achieved at $120^{\circ} \mathrm{C}$. However, the foams are not very uniform and the strands have areas of well foamed and poorly foamed material. This non-uniformity in foaming and strand diameter was increased below $120^{\circ} \mathrm{C}$. This was also apparent in the SEM analysis as the poorly foamed areas were more likely to exist in the SEM cross sections.
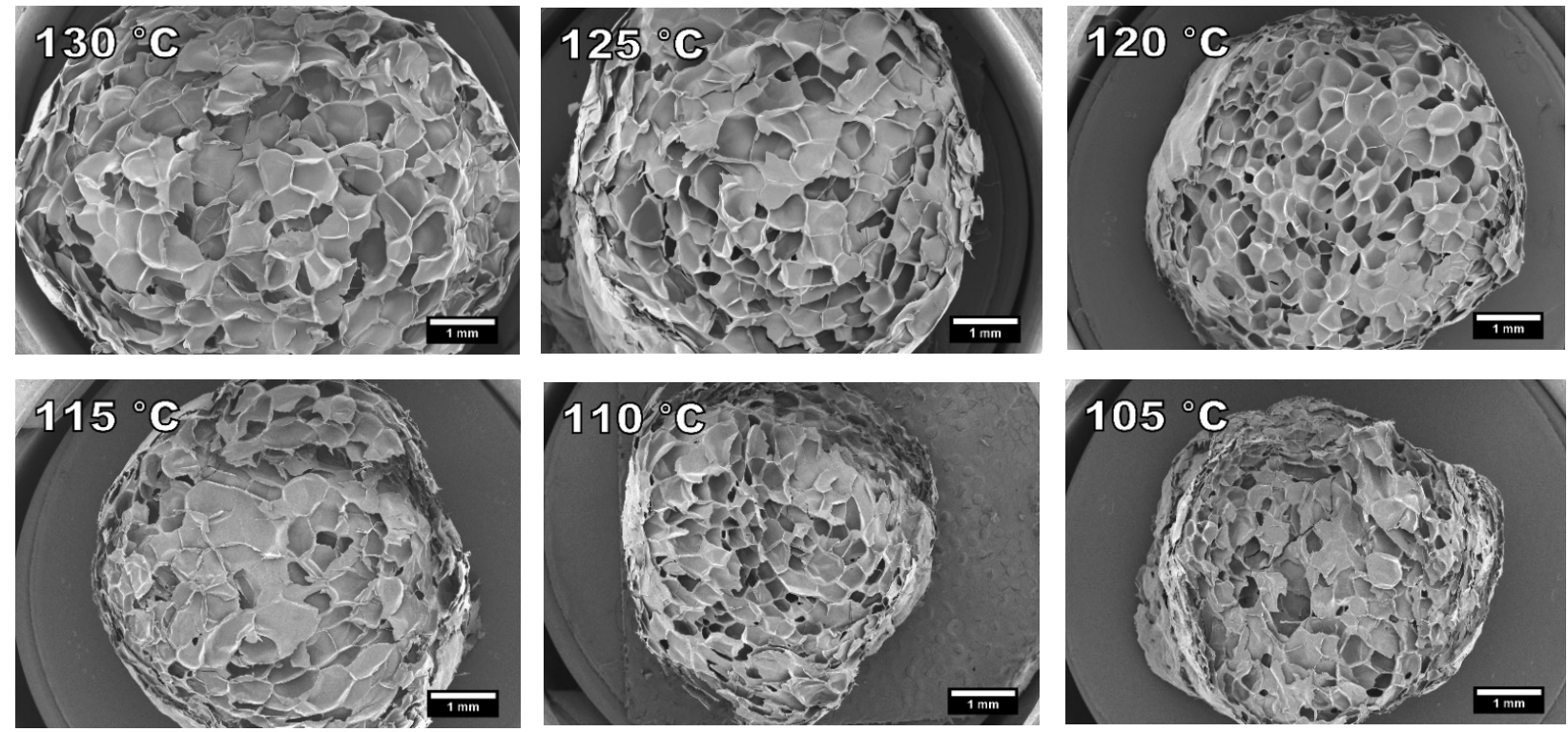

Figure 7. SEM images of prepared cellulose palmitate foams using different foaming temperatures and 3\% IB as a blowing agent. Refer to Table 3. (15× magnification). 
Cell size distribution of samples IB-3_130 ${ }^{\circ} \mathrm{C}$, IB-3_ $120^{\circ} \mathrm{C}$, and IB-3_ $110^{\circ} \mathrm{C}$ were analysed using tomography. The results are presented in Figure 8. Samples foamed at $130{ }^{\circ} \mathrm{C}$ and $110^{\circ} \mathrm{C}$ show remarkably similar distribution in cell size despite differences in SEM analysis. Both samples have a strong presence of small cells $(\leq 150 \mu \mathrm{m})$ but for different reasons. The average cell size is determined by fitting a sphere inside a measured void. Considering the foaming temperature had essentially been too high for IB-3 $3130^{\circ} \mathrm{C}$ and the cells had shrunk or collapsed slightly, the average cell size was also reduced. At $110^{\circ} \mathrm{C}$, the temperature starts to become too low and the material viscosity becomes excessively high. Therefore, it is more difficult for the isobutane to form a large cell into the material. Additionally, at a low temperature, the die pressure is increased which promotes higher cell density and smaller cells. The mean cell size for IB-3_ $130^{\circ} \mathrm{C}$ and IB-3_ $110^{\circ} \mathrm{C}$ is $182 \mu \mathrm{m}$ and $178 \mu \mathrm{m}$, respectively, with similar distribution. IB-3_ $130^{\circ} \mathrm{C}$ has slightly more cells above $150 \mu \mathrm{m}$ and especially above $300 \mu \mathrm{m}$ that can indicate the occurrence of cell coalescence. The well-defined cell structure of Sample IB-3_ $120^{\circ} \mathrm{C}$ is also visible in the tomography data. While the average cell size achieved at $120^{\circ} \mathrm{C}$ is slightly higher at $198 \mu \mathrm{m}$, the cell size distribution is also the narrowest. At $120^{\circ} \mathrm{C}$, the material had a suitable amount of stiffness to stabilize the cell structure, preventing shrinkage while having low enough viscosity for achieving maximal cell expansion.

Foam appearance, SEM images, and tomography data all show differences between the foaming temperatures. However, densities of the foams are surprisingly similar as evident in Table 4. While the differences are small, some conclusions can be established that support previous findings. At the low temperature of $105^{\circ} \mathrm{C}$, the density begins to increase because the foam expansion is restricted due to material solidification. Nevertheless, at the selected temperature range, foaming temperature had little effect on foam density. This is not very common as generally foaming temperature influences density [10,57-60]. Additionally, uniform cell structure can sometimes be achieved at the expense of increased foam density [10]. In the case of cellulose palmitate, relatively uniform cell structure can be achieved with isobutane without sacrificing density.

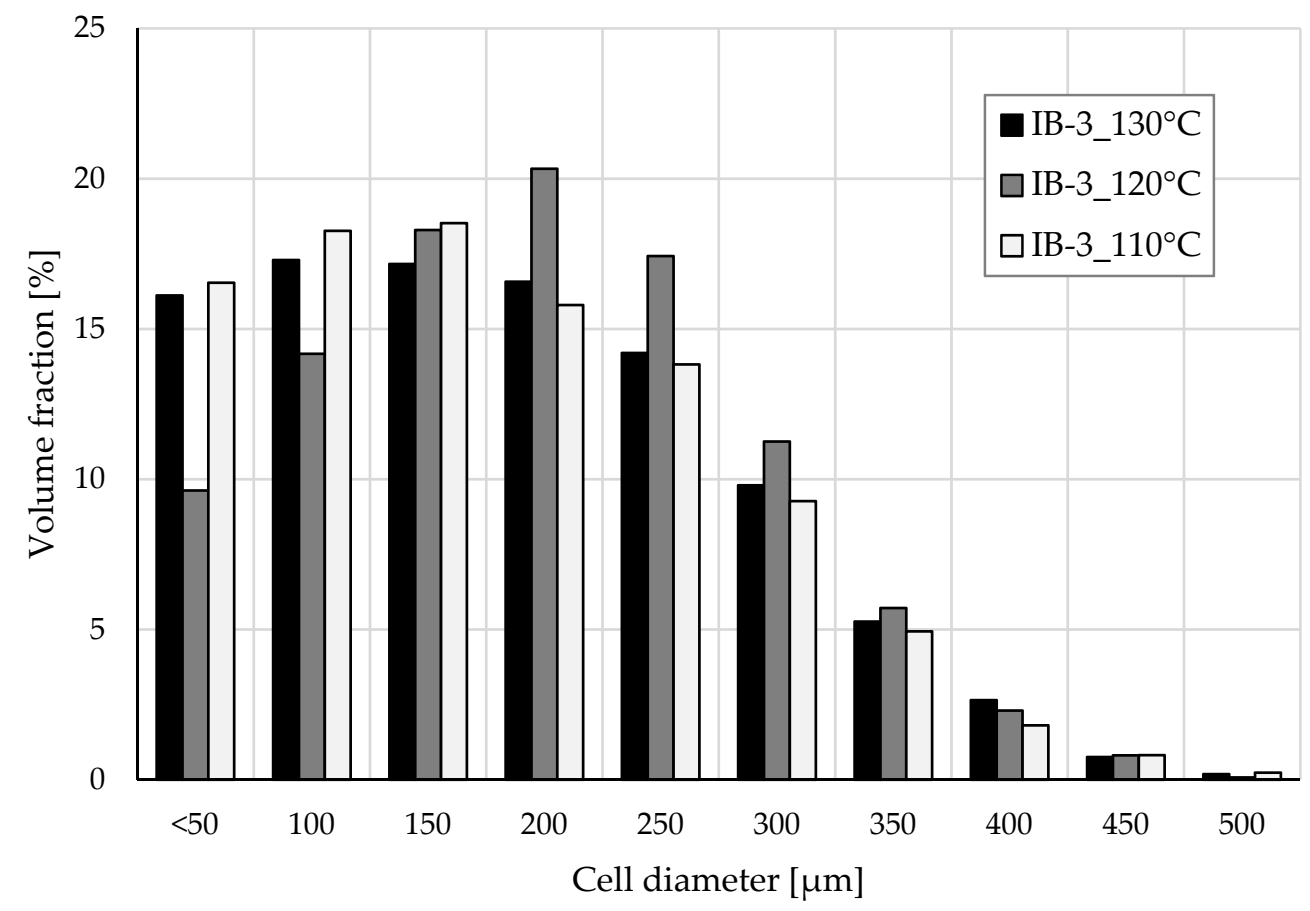

Figure 8. Cell size distribution of selected samples determined with $\mathrm{X} \mu \mathrm{CT}$. 
Table 4. The densities of prepared cellulose palmitate foams using different foaming temperatures and $3 \%$ IB as a blowing agent.

\begin{tabular}{lc}
\hline Sample ID & Density $\left[\mathrm{g} / \mathrm{cm}^{\mathbf{3}}\right]$ \\
\hline IB-3_130 ${ }^{\circ} \mathrm{C}$ & $0.18 \pm 0.00$ \\
IB-3_125 $\mathrm{C}$ & $0.18 \pm 0.01$ \\
IB-3_120 $\mathrm{C}$ & $0.19 \pm 0.00$ \\
IB-3_115 $\mathrm{C}$ & $0.18 \pm 0.01$ \\
IB-3_110 $\mathrm{C}$ & $0.19 \pm 0.01$ \\
IB-3_105 ${ }^{\circ} \mathrm{C}$ & $0.21 \pm 0.01$ \\
\hline
\end{tabular}

\section{Conclusions}

The foamability of cellulose palmitate was tested with three physical blowing agents: isobutane, nitrogen, and carbon dioxide. All three blowing agents were able to foam the material successfully and achieve densities below $0.20 \mathrm{~g} \mathrm{~cm}^{-3}$. However, major differences in foam morphology were noticed between the blowing agents. Nitrogen produced foams with the most uniform cell structure and the smallest average cell size without visible shrinking. Nitrogen was also able to foam the material with a very low dosage of $0.5 \mathrm{wt} \%$. Isobutane produced foams with the largest average cell size and with visible shrinking. Carbon dioxide produced foam with an average cell size between that of nitrogen and isobutane but also with significant shrinking and poor surface quality. A higher amount of isobutane and carbon dioxide than nitrogen was required to foam the material fully.

While the average cell size with isobutane was the largest of the three blowing agents, it was still deemed to be the most suitable blowing agent to conduct foaming temperature optimization studies. Foaming temperatures in the range of $105-130{ }^{\circ} \mathrm{C}$ with $3 \mathrm{wt} \%$ isobutane were tested. While higher radial foam expansions were encountered more often at high temperatures $\left(130{ }^{\circ} \mathrm{C}\right)$ than low temperatures $\left(110-105^{\circ} \mathrm{C}\right)$, foaming temperature had very little effect on foam density. Additionally, cell size distribution developed at high and low temperatures was relatively similar but for different reasons. At high temperatures, foam shrank due to poor cell wall stiffness and rapid gas loss, resulting in a higher number of small cells. At low temperatures, a higher number of small cells were developed due to the high material viscosity and increased die pressure that promotes nucleation. The optimal foaming temperature for cellulose palmitate material with $3 \mathrm{wt} \%$ isobutane was around $120^{\circ} \mathrm{C}$ because at that temperature, the most uniform cell size distribution with low $0.19 \mathrm{~g} \mathrm{~cm}^{-3}$ density was achieved.

Used cellulose palmitate material was rather non-uniform which had an influence on the overall foam quality. The material uniformity has also undoubtedly masked some of the foaming characteristics caused by different blowing agents and foaming temperatures. Nevertheless, clear conclusions were able to be established. Further studies should focus on improving material uniformity for foaming purposes and greater foaming characteristics.

Author Contributions: Conceptualization, T.R., P.W.-K., J.R. and T.M.; methodology, T.R. and T.M.; validation, T.R., P.W.-K. and T.M.; formal analysis, T.R.; investigation, T.R. and P.W.-K.; resources, T.R. and P.W.-K.; writing-original draft preparation, T.R., P.W.-K., J.R. and T.M.; writing-review and editing, T.R., P.W.-K., J.R. and T.M.; visualization, T.R.; supervision, J.R. and T.M.; project administration, T.R. and T.M. All authors have read and agreed to the published version of the manuscript.

Funding: This research received no external funding.

Acknowledgments: The authors would like to thank Enni Luoma and Tuomas Turpeinen for their help with analytical work.

Conflicts of Interest: The authors declare no conflict of interest. 


\section{References}

1. Suh, K.W.; Park, C.P.; Maurer, M.J.; Tusim, M.H.; Genova, R.D.; Broos, R.; Sophiea, D.P. Lightweight Cellular Plastics. Adv. Mater. 2000, 12, 1779-1789. [CrossRef]

2. Landrock, A.H. (Ed.) Handbook of Plastic Foams: Types, Properties, Manufacture, and Applications; Noyes Publications: Park Ridge, NJ, USA, 1995; ISBN 978-0-8155-1357-5.

3. Lee, S.-T.; Park, C.B. (Eds.) Foam Extrusion: Principles and Practice, 2nd ed.; Polymeric Foams Series; CRC Press: Boca Raton, FL, USA, 2014; ISBN 978-1-4398-9860-4.

4. Khemani, K.C. Polymeric Foams: An Overview. In Polymeric Foams; ACS Symposium Series; American Chemical Society: Washington, DC, USA, 1997; Volume 669, pp. 1-7; ISBN 978-0-8412-3516-8.

5. Lee, J.W.S.; Park, C.B.; Kim, S.G. Reducing Material Costs with Microcellular/Fine-Celled Foaming. J. Cell. Plast. 2007, 43, $297-312$. [CrossRef]

6. Gendron, R.; Daigneault, L.E. Continuous Extrusion of Microcellular Polycarbonate. Polym. Eng. Sci. 2003, 43, 1361-1377. [CrossRef]

7. Rokkonen, T.; Peltola, H.; Sandquist, D. Foamability and Viscosity Behavior of Extrusion Foamed PLA-Pulp Fiber Biocomposites. J. Appl. Polym. Sci. 2019, 136, 48202. [CrossRef]

8. Kim, S.G.; Park, C.B.; Sain, M. Foamability of Thermoplastic Vulcanizates Blown with Various Physical Blowing Agents. J. Cell. Plast. 2008, 44, 53-67. [CrossRef]

9. Lee, J.W.S.; Park, C.B. Use of Nitrogen as a Blowing Agent for the Production of Fine-Celled High-Density Polyethylene Foams. Macromol. Mater. Eng. 2006, 291, 1233-1244. [CrossRef]

10. Park, C.B.; Behravesh, A.H.; Venter, R.D. Low Density Microcellular Foam Processing in Extrusion Using CO 2 . Polym. Eng. Sci. 1998, 38, 1812-1823. [CrossRef]

11. Yeh, S.-K.; Yang, J.; Chiou, N.-R.; Daniel, T.; Lee, L.J. Introducing Water as a Coblowing Agent in the Carbon Dioxide Extrusion Foaming Process for Polystyrene Thermal Insulation Foams. Polym. Eng. Sci. 2010, 50, 1577-1584. [CrossRef]

12. Rizvi, G.; Matuana, L.M.; Park, C.B. Foaming of PS/Wood Fiber Composites Using Moisture as a Blowing Agent. Polym. Eng. Sci. 2000, 40, 2124-2132. [CrossRef]

13. Jacob, C.; Dey, S.K. Inert Gases as Alternative Blowing Agents for Extruded Low-Density Polystyrene Foam. J. Cell. Plast. 1995, 31, 38-47. [CrossRef]

14. Heck, R.L. A Review of Commercially Used Chemical Foaming Agents for Thermoplastic Foams. J. Vinyl Addit. Technol. 1998, 4, 113-116. [CrossRef]

15. Li, Q.; Matuana, L.M. Foam Extrusion of High Density Polyethylene/Wood-Flour Composites Using Chemical Foaming Agents. J. Appl. Polym. Sci. 2003, 88, 3139-3150. [CrossRef]

16. Sadik, T.; Pillon, C.; Carrot, C.; Reglero Ruiz, J.-A. DSC Studies on the Decomposition of Chemical Blowing Agents Based on Citric Acid and Sodium Bicarbonate. Thermochim. Acta 2018, 659, 74-81. [CrossRef]

17. Yang, H.-H.; Han, C.D. The Effect of Nucleating Agents on the Foam Extrusion Characteristics. J. Appl. Polym. Sci. 1984, 29, 4465-4470. [CrossRef]

18. Leung, S.N.; Wong, A.; Wang, L.C.; Park, C.B. Mechanism of Extensional Stress-Induced Cell Formation in Polymeric Foaming Processes with the Presence of Nucleating Agents. J. Supercrit. Fluids 2012, 63, 187-198. [CrossRef]

19. Willett, J.L.; Shogren, R.L. Processing and Properties of Extruded Starch/Polymer Foams. Polymer 2002, 43, 5935-5947. [CrossRef]

20. Guan, J.; Hanna, M.A. Functional Properties of Extruded Foam Composites of Starch Acetate and Corn Cob Fiber. Ind. Crops Prod. 2004, 19, 255-269. [CrossRef]

21. Xu, Y.X.; Dzenis, Y.; Hanna, M.A. Water Solubility, Thermal Characteristics and Biodegradability of Extruded Starch Acetate Foams. Ind. Crops Prod. 2005, 21, 361-368. [CrossRef]

22. Guan, J.; Hanna, M.A. Extruding Foams from Corn Starch Acetate and Native Corn Starch. Biomacromolecules 2004, 5, 2329-2339. [CrossRef]

23. Bhatnagar, S.; Hanna, M.A. Properties of Extruded Starch-Based Plastic Foam. Ind. Crops Prod. 1995, 4, 71-77. [CrossRef]

24. Keshtkar, M.; Nofar, M.; Park, C.B.; Carreau, P.J. Extruded PLA/Clay Nanocomposite Foams Blown with Supercritical CO2. Polymer 2014, 55, 4077-4090. [CrossRef]

25. Nofar, M.; Park, C.B. Poly (Lactic Acid) Foaming. Prog. Polym. Sci. 2014, 39, 1721-1741. [CrossRef]

26. Mihai, M.; Huneault, M.A.; Favis, B.D. Rheology and Extrusion Foaming of Chain-Branched Poly(Lactic Acid). Polym. Eng. Sci. 2010, 50, 629-642. [CrossRef]

27. Matuana, L.M.; Faruk, O.; Diaz, C.A. Cell Morphology of Extrusion Foamed Poly(Lactic Acid) Using Endothermic Chemical Foaming Agent. Bioresour. Technol. 2009, 100, 5947-5954. [CrossRef]

28. Zepnik, S.; Hildebrand, T.; Kabasci, S.; Ra-dusch, H.-J.; Wodke, T. Cellulose Acetate for Thermoplastic Foam Extrusion. In Cellulose-Biomass Conversion; De Ven, T.V., Kadla, J., Eds.; InTech: Rijeka, Croatia, 2013; pp. 17-44. [CrossRef]

29. Jacobs, L.J.M.; Hurkens, S.A.M.; Kemmere, M.F.; Keurentjes, J.T.F. Porous Cellulose Acetate Butyrate Foams with a Tunable Bimodality in Foam Morphology Produced with Supercritical Carbon Dioxide. Macromol. Mater. Eng. 2008, 293, $298-302$. [CrossRef] 
30. Zepnik, S.; Kabasci, S.; Kopitzky, R.; Radusch, H.-J.; Wodke, T. Extensional Flow Properties of Externally Plasticized Cellulose Acetate: Influence of Plasticizer Content. Polymers 2013, 5, 873-889. [CrossRef]

31. Hopmann, C.; Windeck, C.; Hendriks, S.; Zepnik, S.; Wodke, T. Extrusion Foaming of Thermoplastic Cellulose Acetate from Renewable Resources Using a Two-Component Physical Blowing Agent System. AIP Conf. Proc. 2014, 1593, 116-120. [CrossRef]

32. Hendriks, S.; Hopmann, C.; Zepnik, S. Extrusion Foaming of Thermoplastic Cellulose Acetate Sheets with HFO-1234ze and Co-Blowing Agents. Polym. Eng. Sci. 2018, 58, E182-E188. [CrossRef]

33. Liao, Q.; Tsui, A.; Billington, S.; Frank, C.W. Extruded Foams from Microbial Poly(3-Hydroxybutyrate-Co-3-Hydroxyvalerate) and Its Blends with Cellulose Acetate Butyrate. Polym. Eng. Sci. 2012, 52, 1495-1508. [CrossRef]

34. Zepnik, S.; Hendriks, S.; Kabasci, S.; Radusch, H.-J. Foam Extrusion Behavior, Morphology, and Physical Foam Properties of Organic Cellulose Ester. J. Mater. Res. 2013, 28, 2394-2400. [CrossRef]

35. Mohanty, A.K.; Wibowo, A.; Misra, M.; Drzal, L.T. Development of Renewable Resource-Based Cellulose Acetate Bioplastic: Effect of Process Engineering on the Performance of Cellulosic Plastics. Polym. Eng. Sci. 2003, 43, 1151-1161. [CrossRef]

36. Willberg-Keyriläinen, P.; Talja, R.; Asikainen, S.; Harlin, A.; Ropponen, J. The Effect of Cellulose Molar Mass on the Properties of Palmitate Esters. Carbohydr. Polym. 2016, 151, 988-995. [CrossRef]

37. Willberg-Keyriläinen, P.; Vartiainen, J.; Harlin, A.; Ropponen, J. The Effect of Side-Chain Length of Cellulose Fatty Acid Esters on Their Thermal, Barrier and Mechanical Properties. Cellulose 2017, 24, 505-517. [CrossRef]

38. Willberg-Keyriläinen, P.; Orelma, H.; Ropponen, J. Injection Molding of Thermoplastic Cellulose Esters and Their Compatibility with Poly(Lactic Acid) and Polyethylene. Materials 2018, 11, 2358. [CrossRef] [PubMed]

39. Willberg-Keyriläinen, P.; Ropponen, J.; Alakomi, H.-L.; Vartiainen, J. Cellulose Fatty Acid Ester Coated Papers for Stand-up Pouch Applications. J. Appl. Polym. Sci. 2018, 135, 46936. [CrossRef]

40. Willberg-Keyriläinen, P.; Rokkonen, T.; Malm, T.; Harlin, A.; Ropponen, J. Melt Spinnability of Long Chain Cellulose Esters. J. Appl. Polym. Sci. 2020, 137, 49588. [CrossRef]

41. Hildebrand, T.; Rüegsegger, P. A New Method for the Model-Independent Assessment of Thickness in Three-Dimensional Images. J. Microsc. 1997, 185, 67-75. [CrossRef]

42. Lee, S.T.; Kareko, L.; Jun, J. Study of Thermoplastic PLA Foam Extrusion. J. Cell. Plast. 2008, 44, 293-305. [CrossRef]

43. Marcilla, A.; Beltrán, M. Mechanisms of plasticizers action. In Handbook of Plasticizers, 3rd ed.; Elsevier: Amsterdam, The Netherlands, 2017; pp. 119-134; ISBN 978-1-895198-97-3.

44. Royer, J.R.; Gay, Y.J.; Desimone, J.M.; Khan, S.A. High-Pressure Rheology of Polystyrene Melts Plasticized with CO2: Experimental Measurement and Predictive Scaling Relationships. J. Polym. Sci. Part B Polym. Phys. 2000, 38, 3168-3180. [CrossRef]

45. Maio, E.D.; Mensitieri, G.; Iannace, S.; Nicolais, L.; Li, W.; Flumerfelt, R.W. Structure Optimization of Polycaprolactone Foams by Using Mixtures of CO2 and N2 as Blowing Agents. Polym. Eng. Sci. 2005, 45, 432-441. [CrossRef]

46. Sato, Y.; Fujiwara, K.; Takikawa, T.; Takishima, S.; Masuoka, H. Solubilities and Diffusion Coefficients of Carbon Dioxide and Nitrogen in Polypropylene, High-Density Polyethylene, and Polystyrene under High Pressures and Temperatures. Fluid Phase Equilibria 1999, 162, 261-276. [CrossRef]

47. Zhang, H.; Liu, T.; Li, B.; Li, H.; Cao, Z.; Jin, G.; Zhao, L.; Xin, Z. Anti-Shrinking Foaming of Polyethylene with CO2 as Blowing Agent. J. Supercrit. Fluids 2020, 163, 104883. [CrossRef]

48. Chen, J.; Zhang, J.; Feng, Y.; He, J.; Zhang, J. Effect of Molecular Structure on the Gas Permeability of Cellulose Aliphatate Esters. Chin. J. Polym. Sci. 2014, 32, 1-8. [CrossRef]

49. Lemmon, E.; McLinden, M.; Friend, D. Thermophysical Properties of Fluid Systems. In NIST Chemistry WebBook; NIST Standard Reference Database Number, 69, Linstrom, P., Mallard, W., Eds.; National Institute of Standards and Technology: Gaithersburg, MD, USA, 2018; p. 20899. [CrossRef]

50. Azdast, T.; Hasanzadeh, R. Increasing Cell Density/Decreasing Cell Size to Produce Microcellular and Nanocellular Thermoplastic Foams: A Review. J. Cell. Plast. 2020. [CrossRef]

51. Banerjee, R.; Ray, S.S. Foamability and Special Applications of Microcellular Thermoplastic Polymers: A Review on Recent Advances and Future Direction. Macromol. Mater. Eng. 2020, 305, 2000366. [CrossRef]

52. Matuana, L.M.; Diaz, C.A. Study of Cell Nucleation in Microcellular Poly(Lactic Acid) Foamed with Supercritical CO2 through a Continuous-Extrusion Process. Ind. Eng. Chem. Res. 2010, 49, 2186-2193. [CrossRef]

53. Park, C.B.; Baldwin, D.F.; Suh, N.P. Effect of the Pressure Drop Rate on Cell Nucleation in Continuous Processing of Microcellular Polymers. Polym. Eng. Sci. 1995, 35, 432-440. [CrossRef]

54. Wong, A.; Mark, L.H.; Hasan, M.M.; Park, C.B. The Synergy of Supercritical CO2 and Supercritical N2 in Foaming of Polystyrene for Cell Nucleation. J. Supercrit. Fluids 2014, 90, 35-43. [CrossRef]

55. Kim, S.G.; Lee, J.W.S.; Park, C.B.; Sain, M. Enhancing Cell Nucleation of Thermoplastic Polyolefin Foam Blown with Nitrogen. J. Appl. Polym. Sci. 2010, 118, 1691-1703. [CrossRef]

56. Naguib, H.E.; Park, C.B.; Reichelt, N. Fundamental Foaming Mechanisms Governing the Volume Expansion of Extruded Polypropylene Foams. J. Appl. Polym. Sci. 2004, 91, 2661-2668. [CrossRef]

57. Wang, M.; Liu, J.; Hu, J.; Zhou, N. The Effect of Processing Parameters on Cell Structure and Mechanical Properties of ExtrusionFoamed Poly(Vinyl Chloride) Sheets. J. Vinyl Addit. Technol. 2016, 22, 377-383. [CrossRef] 
58. Lee, C.H.; Lee, K.-J.; Jeong, H.G.; Kim, S.W. Growth of Gas Bubbles in the Foam Extrusion Process. Adv. Polym. Technol. 2000, 19, 97-112. [CrossRef]

59. Kumar, V.; Nadella, K.; Branch, G.; Flinn, B. Extrusion of Microcellular Foams Using Pre-Saturated Pellets and Solid-State Nucleation. Cell. Polym. 2004, 23, 369-385. [CrossRef]

60. Lee, S.-T.; Lee, K. Surrounding Temperature Effects on Extruded Polyethylene Foam Structure. Adv. Polym. Technol. 2000, 19, 87-96. [CrossRef] 